\title{
A rapid and simple method for screening fungi for extracellular protease enzymes
}

\author{
Thirunavukkarasu N $\mathbf{N}^{1}$, Suryanarayanan $\mathrm{TS}^{2 *}$, Rajamani $\mathrm{T}^{1,2}$ and Paranetharan \\ MS $^{1,2}$
}

\author{
${ }^{1} P G \&$ Research Department of Botany, Ramakrishna Mission Vivekananda College, Chennai 600004 \\ ${ }^{2}$ Vivekananda Institute of Tropical Mycology, Ramakrishna Mission Vidyapith, Chennai 600004 \\ *Corresponding author: t_sury2002@yahoo.com
}

Thirunavukkarasu N, Suryanarayanan TS, Rajamani T, Paranetharan MS 2017 - A rapid and simple method for screening fungi for extracellular protease. Mycosphere 8(1), 131-136, Doi $10.5943 /$ mycosphere/8/1/12

\begin{abstract}
A simple and rapid method to detect extracellular protease produced by fungi is described. This method is more sensitive than the conventional agar plate method and could be used for screening a large number of samples in a short time. It also enables the visualization of different types of proteases. This method could be used with suitable modifications to detect other extracellular enzymes.
\end{abstract}

Keywords- Agar plate assay- enzyme assay -fungal enzymes - fungal protease

\section{Introduction}

Fungal proteases are used in the food, dairy, detergent, leather and pharmaceutical industries. They are also used for bioremediation and production of therapeutic peptides (Wu et al. 2006, Yike 2011). Fungal enzymes are more suited for industrial applications as fungi are easily cultured and are fast growing; many fungal enzymes are extracellular and are amenable to manipulations. Furthermore, fungal proteases are more diverse and exhibit wider substrate specificity (Kudryavtseva et al. 2008). Apart from engineering known enzymes for better efficiency by methods including directed evolution and rational design, screening microbes from relatively unexplored ecological niches for novel enzymes with desirable properties is a common method for improving the current industrial enzyme scenario (Kumar et al. 2011, Li et al. 2012). Fungal endophytes are non-disease causing endosymbionts of plants and comprise a group of different lineages (Guo et al. 2001, Hyde \& Soytong 2008). Numerous studies have denoted the potential of endophytes to produce secondary metabolites exhibiting different bioactivities (Suryanarayanan et al. 2009, Kaushik et al. 2014, Mohana Kumara et al. 2014, Chen et al. 2016). Enzymes are produced in nature by endophytic fungi (Promputtha et al. 2010), yet they have not been explored intensively for their enzyme range (Suryanarayanan et al. 2012). Using endophytes, we describe here a simple and rapid qualitative assay for secreted fungal proteases.

\section{Materials \& Methods Fungal strains}


Fungal endophytes residing in the inside the root, bark, or leaf tissues of some plants including forest trees (Western Ghats, Tamilnadu state, southern India) and mangrove forest (Pichavaram, Tamilnadu state, southern India) and maintained in the culture collection of VINSTROM were used in this study. Sixty one endophyte strains were screened to detect secreted protease enzymes by a qualitative dot blot method. This method was earlier used by us for detecting extracellular chitinase and chitosanase of endophytes (Govinda Rajulu et al. 2011); it was suitably modified for detecting proteases in the current study.

\section{Detection of Protease enzyme}

Preparation of samples

Each fungal isolate was grown in $100 \mathrm{ml}$ Potato Dextrose medium (200 g Potato, $20 \mathrm{~g}$ Dextrose, $1000 \mathrm{ml}$ distilled water, $\mathrm{pH}$ 6.0) for five days as static culture at $26{ }^{\circ} \mathrm{C}$. After incubation, the mycelium was filtered and the culture filtrate was dialyzed for $15 \mathrm{~h}$ against distilled water. The dialyzed culture filtrate was lyophilized and used as crude enzyme source for detecting proteases.

Gel preparation for spot assay and visualization of enzyme activity

A dot blot method described by Govinda Rajulu et al (2011) for detecting chitin modifying enzymes of fungi was modified suitably and used. A gel was prepared by mixing a solution containing $1 \mathrm{ml}$ of $30 \%$ acrylamide/bisacrylamide, $0.4 \mathrm{ml}$ substrate $(2 \%$ autoclaved bacteriological gelatin - Qualigens 24345), $2.3 \mathrm{ml}$ of $50 \mathrm{mM}$ TrisHCl buffer ( $\mathrm{pH} 9.0$ ), $0.003 \mathrm{ml}$ of $100 \%$ TEMED and $0.003 \mathrm{ml}$ of $40 \%$ ammonium persulphate and poured in a gel cassette. After polymerization, it was topped with the above mixture having Bis Tris buffer $(\mathrm{pH} \mathrm{7.0)}$ or sodium acetate buffer ( $\mathrm{pH}$ 5.0). Thus, a composite gel made of gel strips of $\mathrm{pH} 5.0, \mathrm{pH} 7.0$ and $\mathrm{pH} 9.0$ was obtained.10 mg of the lyophilized culture filtrate of each fungus (crude enzyme source) was mixed with $1 \mathrm{ml}$ of appropriate buffer (buffers of different $\mathrm{pH}$ used for gel preparation) and centrifuged at $14000 \mathrm{rpm}$ for 5 minutes $\left(20^{\circ} \mathrm{C}\right) ; 5 \mu \mathrm{l}$ of the supernatant of this solution was spotted on the appropriate gel fields of the composite gel. The gel was incubated for 8-10 hours, stained with $0.025 \%$ Coomassie Brilliant Blue ( $\mathrm{R} 250$ ) for 3 hours, washed with distilled water and then observed for the presence of clear zones on the deep blue gels which indicated enzyme activity. As controls, alkaline protease (Sigma P8038) and acidic protease (Sigma P0107) were dissolved in appropriate buffers and $5 \mu \mathrm{l}$ of this solution (fresh or autoclaved) was spotted along with the samples on the gels.

\section{Results}

Protease action was clearly visible as a colourless spot on the dark blue background of the gel (Fig. 1). We observed that out of the 61 endophyte isolates, 25, 24 and 20 elaborated acidic, neutral and alkaline protease(s) respectively (Table 1). Interestingly, 17 isolates were positive for all the three types of proteases.

\section{Discussion}

Agar plate assays are most commonly used for detecting secreted proteases of fungi. This involves amending agar culture medium with a protein substrate such as casein or milk and growing the test fungus on this medium. Production of protease is visualized by the appearance of a clear zone around the fungal colony indicative of the hydrolysis of protein. Flooding the agar plate with a solution of Tri Chloro Acetic acid (Larsen et al. 1998) or Tannic acid (Saran et al. 2007) enhances the visibility of the cleared zone. In the dot blot assay, we used Coomassie Brilliant Blue stain which is routinely used for staining proteins separated by SDS-PAGE. This stain forms a complex with the protein and is sensitive enough to visualize proteins as low as $30 \mathrm{ng}$ (Simpson 2010). It stains the gelatin substrate present in the gel deep blue and the clearing of this colour in the gel indicates protease action. The dot blot method is superior to the conventional agar plate assay in several ways. It is more sensitive and could be used for screening a large number of samples in a short time. By altering the $\mathrm{pH}$ of the supporting gel, it effectively detects different 
Table 1 Detection of protease activity of endophytes by dot blot assay.

\begin{tabular}{|c|c|c|c|c|}
\hline \multirow[t]{2}{*}{ Endophyte } & \multirow[t]{2}{*}{ Host } & \multicolumn{3}{|c|}{ pH } \\
\hline & & 5.0 & 7.0 & 9.0 \\
\hline Alternaria alternata & Elaeodendron glaucum / L & - & - & - \\
\hline Alternaria sp. & Cordia obliqua / L & - & - & - \\
\hline Alternaria sp. & Acacia chundra / L & - & - & - \\
\hline Aureobasidium pullulans & Spinifex littoreus / L & - & - & - \\
\hline A. pullulans & Euonymus angulatus / L & - & - & - \\
\hline Beltrania rhombica & Symplocos obtusa / L & + & - & - \\
\hline Chaetomium fibripilium & Gmelina asiatica / B & - & - & - \\
\hline Chaetomium sp. & Bruguiera cylindrica / L & - & - & - \\
\hline Chaetomium sp. & Unidentified / S & - & + & - \\
\hline Chaetomium sp. & Avicennia marina / $\mathrm{R}$ & + & + & + \\
\hline Colletotrichum acutatum & Neolitsea zeylanica / L & + & + & + \\
\hline Colletotrichum sp. & Syzygium cumini /L & - & - & - \\
\hline Colletotrichum sp. & Murraya paniculata /L & - & - & + \\
\hline Colletotrichum sp. & Kydia calycina / L & - & - & - \\
\hline Colletotrichum sp. & Unidentified / L & + & + & + \\
\hline Colletotrichum sp. & Semecarpus anacardium / L & + & + & + \\
\hline Colletotrichum sp. & Rhizophora apiculata / L & - & - & - \\
\hline Colletotrichum sp. & Rhizophora apiculata / L & + & + & + \\
\hline Corynespora cassicola & Terminalia crenulata / L & - & - & - \\
\hline C. cassicola & Butea monosperma / L & + & + & + \\
\hline Cryptosporiopsis sp. & Syzygium calophyllifolium / L & - & - & - \\
\hline Curvularia lunata & Ilex wightiana / B & - & - & - \\
\hline Curvularia sp. & Acacia leucophloea / L & + & + & + \\
\hline Curvularia sp. & Macaranga peltata / L & - & + & - \\
\hline Cylindrocladium sp. & Cinnamomum malabatrum / L & + & - & - \\
\hline Drechslera sp. & Vinca rosea / L & - & - & - \\
\hline Fusarium sp. & Rhizophora apiculata/ R & + & + & + \\
\hline Fusarium sp. & Pongamia pinnata / B & - & - & - \\
\hline Glomerella cingulata & Canthium parviflorum / L & + & + & + \\
\hline Nigrospora oryzae & Unidentified / L & + & + & - \\
\hline N. oryzae & Daphniphyllum neilgherrense / L & - & - & - \\
\hline Nodulisporium sp. & Withania somnifera / L & - & - & - \\
\hline Nodulisporium sp. & Glochidion sp. / B & + & + & + \\
\hline Penicillium sp. & Phyllanthus emblica / B & - & - & - \\
\hline Pestalotiopsis sp. & Rhizophora apiculata / L & + & + & + \\
\hline Pestalotiopsis sp. & Litsea stocksii / L & + & + & + \\
\hline Phoma sp. & Unidentified / S & + & - & - \\
\hline Phoma sp. & Avicennia marina / $\mathrm{R}$ & + & + & - \\
\hline Phomopsis sp. & Avicennia marina / $\mathrm{R}$ & + & + & + \\
\hline Phomopsis sp. & Acacia suma / L & - & - & - \\
\hline Phyllosticta capitalensis & Turpinia nepalensis / L & - & - & - \\
\hline P. capitalensis & Bridelia retusa / L & - & - & - \\
\hline P. capitalensis & Ougeinia oojeinensis / L & - & - & - \\
\hline Pithomyces graminicola & Litse a floribunda / L & - & - & - \\
\hline Sordaria sp. & Canthium parviflorum / L & - & - & - \\
\hline Sterile form & Avicennia marina / R & + & + & + \\
\hline Sterile form & Rhizophora apiculata / R & + & + & + \\
\hline Taeniolella sp. & Ilex wightiana / L & - & - & - \\
\hline Talaromyces sp. & Avicennia marina / $\mathrm{R}$ & - & - & + \\
\hline
\end{tabular}


Table 1 continued.

\begin{tabular}{llccc}
\hline Endophyte & Host & \multicolumn{3}{c}{ pH } \\
\cline { 3 - 5 } & & $\mathbf{5 . 0}$ & $\mathbf{7 . 0}$ & $\mathbf{9 . 0}$ \\
\hline Torulomyces sp. & Randia dumetorum / L & - & - & - \\
Trichoderma sp. & Azadirachta indica / B & - & - & - \\
Trichoderma sp. & Pedilanthus tithymaloides / L & - & - & - \\
Trichoderma sp. & Unidentfied / L & - & - & - \\
Xylariaceous form & Cassia fistula / L & + & - & + \\
Xylariaceous form & Anogeissus latifolia / L & + & + & + \\
Xylariaceous form & Stereospermum tetragonum / L & - & - & - \\
Xylariaceous form & Syzygium calophyllifolium / L & - & - & - \\
Xylariaceous form & Ziziphus jujuba / L & + & + & + \\
Xylariaceous form & Butea monosperma/ L & + & + & - \\
Xylariaceous form & Dalbergia latifolia / L & - & + & - \\
Xylariaceous form & Semecarpus anacardium / B & + & + & - \\
& & & & \\
\hline Positive strains & & $\mathbf{2 5}$ & $\mathbf{2 4}$ & $\mathbf{2 0}$ \\
\hline
\end{tabular}

$\mathrm{L}=$ isolated from leaf, $\mathrm{B}=$ isolated from bark, $\mathrm{S}=$ isolated from stem, $\mathrm{R}=$ isolated from root

proteases. Thus, large numbers of samples could be screened rapidly and potential producers couldbe identified for further detailed studies and use. Furthermore, the dot blot method could be modified suitably for detecting many other secreted enzymes such as amylase, and l-asparaginase. Recent studies show that fungal endophytes are a source of therapeutic and industrial enzymes such as chitin modifying enzymes (Govinda Rajulu et al. 2011), l-asparaginase (Nagarajan et al. 2014) and xylan-degrading enzymes (Thirunavukkarasu et al. 2015). Our present study shows that they could be a novel source of different proteases.

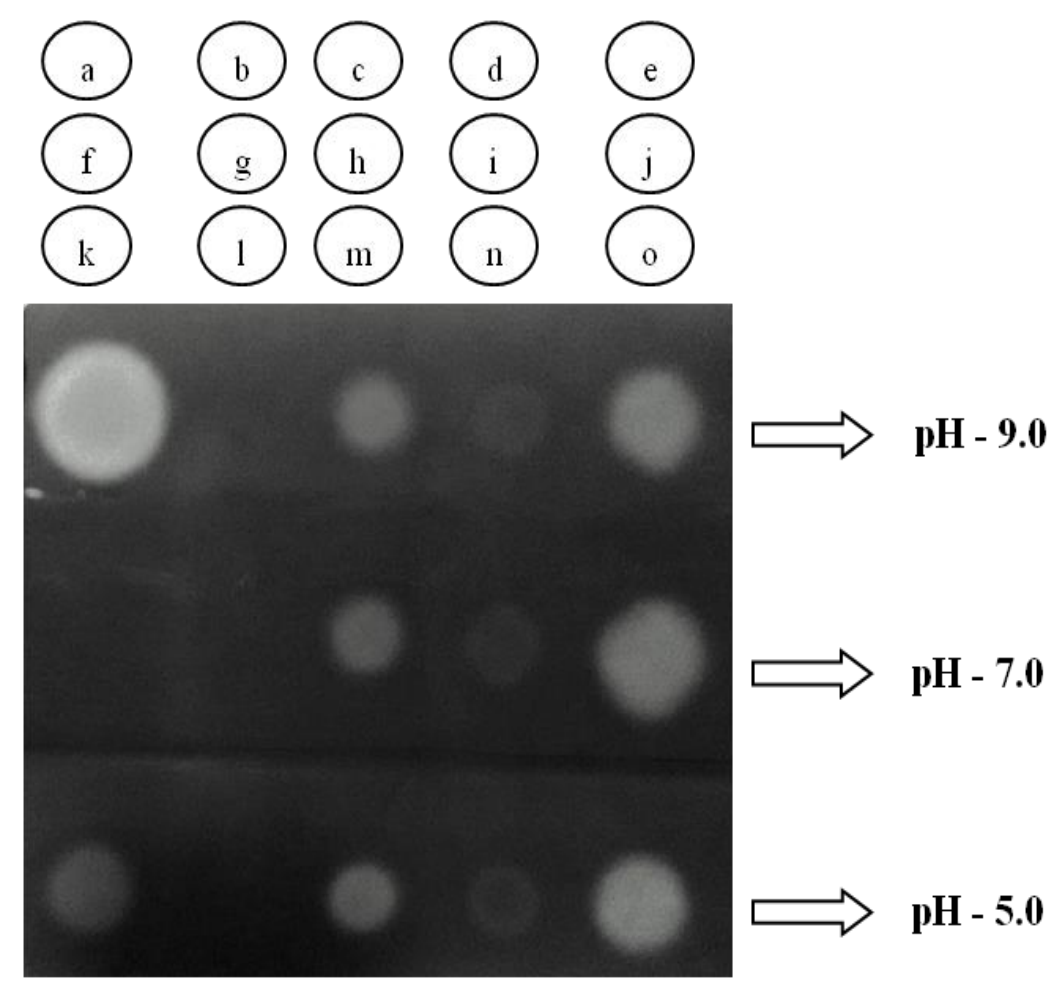

Figure 1 - Detection of protease activity of endophytes by dot blot assay. a Acidic protease sample. b Autoclaved acidic protease sample. c, h, m Pestalotiopsis sp. (Litsea stocksii / L). d, i, $\mathbf{n}$ Pithomyces graminicola (Litsea floribunda / L). e, j, o Curvularia sp. (Acacia leucophloea / L). f, $\mathbf{g}$ Not spotted. k Alkaline protease sample. I Autoclaved alkaline protease sample. 


\section{Acknowledgements}

TSS thanks the Secretary, Ramakrishna Mission Vidyapith, Chennai, for providing research facilities. NT thanks the Department of Science and Technology, Government of India for funds through the Science and Engineering Research Board project (SB/EMEQ-005/2013).

\section{References}

Chen C, Hu SY, Luo DQ, Zhu SY, Zhou CQ. 2016 - Potential antitumor agent from the endophytic fungus Pestalotiopsis photiniae induces apoptosis via the mitochondrial pathway in HeLa cells. Oncology Reports 30, 1773-1781.

Govinda Rajulu MB, Thirunavukkarasu N, Suryanarayanan TS, Ravishankar JP, El Gueddari NE, Moerschbacher BM. 2011 - Chitinolytic enzymes from endophytic fungi. Fungal Diversity 47, 43-53.

Guo LD, Hyde KD, Liew ECY 2001 - Detection and taxonomic placement of endophytic fungi within frond tissues of Livistona chinensis based on rDNA sequences. Molecular Phylogenetics \& Evolution 20, 1-13.

Hyde KD, Soytong K 2008 - The fungal endophyte dilemma. Fungal Diversity 33: 163-173.

Kaushik NK, MuraliTS, Sahal D, Suryanarayanan TS. 2014 - A search for antiplasmodial metabolites among fungal endophytes of terrestrial and marine plants of southern India. Acta Parasitologica 59, 745-757.

Kudryavtseva OA, Dunaevsky YE, Kamzolkina OV, Belozersky MA. 2008- Fungal proteolytic enzymes: Features of the extracellular proteases of xylotrophic basidiomycetes. Microbiology 77, 643-653.

Kumar L, Awasthi G, Singh B. 2011- Extremophiles: a novel source of industrially important enzymes. Biotechnology 10, 121-135.

Larsen MD, Kristiansen KR, Hansan TK. 1998 - Characterization of the proteolytic activity of starter cultures of Penicillium roqueforti for production of blue veined cheeses. International Journal of Food Microbiology 43, 215-221.

Li S, Yang X, Yang S, Zhu M, Wang X. 2012 - Technology prospecting on enzymes: application, marketing and engineering. Computational and Structural Biotechnology Journal 2, 1-11.

Mohana Kumara P, Soujanya KN, Ravikanth G, Vasudeva R, Ganeshaiah KN, Uma Shaanker R. 2014 - Production of the chromane alkaloid, rohitukine and its attenuation in endophytic fungi isolated from Dysoxylum binectariferum Hook.f and Amoora rohituka (Roxb).Wight \& Arn. Phytomedicine 21, 54-546.

Nagarajan A, Thirunavukkarasu N, Suryanarayanan TS, Gummadi SN. 2014 - Screening and isolation of novel glutaminase free 1-asparaginase from fungal endophytes. Research Journal of Microbiology 9, 163-176.

Promputtha I, Hyde KD, McKenzie EHC, Peberdy JF; Lumyong, S. 2010 - Can leaf degrading enzymes provide evidence that endophytic fungi becoming saprobes? Fungal Diversity 41, 89-99.

Saran S, Isar J, Saxena RK. 2007 - A modified method for the detection of microbial proteases on agar plates using Tannic acid. Journal of Biochemical and Biophysical Methods 70, 697-699.

Simpson RJ. 2010 - Rapid Coomassie blue staining of protein gels. Cold Spring Harbor protocols doi: $10.1101 /$ pdb.prot5413.

Suryanarayanan TS, Thirunavukkarasu N, Govindarajulu MB, Sasse F, Jansen R, Murali TS. 2009 - Fungal endophytes and bioprospecting. Fungal Biology Reviews 23, 9-19.

Suryanarayanan TS, Thirunavukkarasu N, Govinda Rajulu MB, Gopalan V. 2012 - Fungal endophytes: An untapped source of biocatalysts. Fungal Diversity 54, 19-30.

Thirunavukkarasu N, Jahnes B, Broadstock A, Govinda Rajulu MB, Murali TS, Gopalan V, Suryanarayanan TS. 2015 - Screening marine-derived endophytic fungi for xylan-degrading enzymes. Current Science109:112-120. 
Wu TY, Mohammada AW, Jahim JM. 2006 - Investigations on protease production by a wild-type Aspergillus terreus strain using diluted retentate of pre-filtered palm oil mill effluent (POME) as substrate. Enzyme and Microbial Technology 39, 1223-1229.

Yike I. 2011 - Fungal proteases and their pathophysiological effects. Mycopathologia 171, 299323. 